\title{
PROGEEDINGS
}

OF THE

\section{ROYAL SOCIETY OF EDINBURGH}




\title{
P R O G E E D I N G S
}

\author{
OF \\ THE ROYAL SOCIETY \\ OF EDINBURGH
}

VOL. LIV.

I 933 - I 934

E D I N B U R G H

PRINTED BY NEILL AND COMPANY, LIMITED

MCM XXXV 


\section{CONTENTS}

I. On Fitting Polynomials to Weighted Data by Least Squares. By A. C. Aitken, M.A., D.Sc., University of Edinburgh. Issued separately November 29, I933,

2. On Fitting Polynomials to Data with Weighted and Correlated Errors. By A. C. Aitken, M.A., D.Sc., University of Edinburgh. Issued separately November 29, 1933 ,

3. The Cruciform Muscle of Lamellibranchs. By Alastair Graham, M.A., B.Sc. (From the Department of Zoology, University of Sheffield.) Communicated by Professor J. H. Ashworth, F.R.S. (With Six Text-figures.) Issued separately February 26, 1934,

4. The Developmental Stages of Euchata norvegica, Boeck. By A. G. Nicholls, Ph.D., Assistant Naturalist, Marine Station, Millport. Communicated by Professor J. H. Ashworth, F.R.S. (With Eight Text-figures.) Issued separately March I 5, I934,

5. The Weight and Chemical Composition of Euchata norvegica, Boeck. By A. P. Orr, M.A., B.Sc., A.I.C., Chemist, Marine Station, Millport. Communicated by Professor J. H. Ashworth, F.R.S. Issued separately March I 5 , 1934, .

6. Studies on the Reproductive System in the Guinea-Pig: Observations on the Ovaries, with special reference to the Corpus Luteum. By Thomas Nicol, M.B., Ch.B., F.R.C.S.E., Senior Lecturer in Anatomy, University of Glasgow. Issued separately March I 5, I934,

*7. Spermatogenesis in Drosophila pseudo-obscura Frolowa. II. The Cytological Basis of Sterility in Hybrid Males of Races A and B. By P. Ch. Koller, D.Sc., Institute of Animal Genetics, University of Edinburgh. Communicated by Professor F. A. E. Crew, M.D. (With Thirty-nine Text-figures.) Issued separately June 4, I934,

8. The Atomic Weight of the Calcium contained in Very Old Potassium-rich Minerals occurring at Portsoy, Banffshire, and at Cape Wrath, Sutherlandshire. By William W. Smith and Thomas Tait. Communicated by Professor James Kendall, F.R.S. Issued separately June 21, I934, 
9. The Photoelectric Thresholds of some Turned Metallic Surfaces. By J. S. Hunter, B.Sc., Carnegie Research Schotar, University of St Andrews. Communicated by Professor H. S. Allen, F.R.S. (With Two Figures.) Issued separately June 21, I934,

10. Note on the Electron Configurations $p^{2} s, p^{4} s$. By Robert Schlapp, M.A., Ph.D., University of Edinburgh. Issued separately July 5, I934,

II. Graphical Classification of Carbonaceous Minerals: The Mineral Oils. By Professor Henry Briggs, D.Sc., Ph.D., University of Edinburgh. (With Chart.) Issued separately July I6, 1934.

12. Products of the Natural Development of Coal and Oil. By Professor Henry Briggs, D.Sc., Ph.D., University of Edinburgh. (With Two Figures.) Issued separately July 16, 1934,

13. Some Integrals, with respect to their Degrees, of Associated Legendre Functions. By Professor T. M. MacRobert, M.A., D.Sc., University of Glasgow. Issued separately July 16, 1934,

14. Fifty Years Ago, in the Royal Society of Edinburgh. By Professor D'Arcy Wentworth Thompson. (With Two Plates.) (An Address delivered, at the request of the Council, on May 7 , 1934, in commemoration of the 150 th Year of the Society.) Issued separately August 8, 1934,

I 5. The Structure and Relationships of Lamellibranchs possessing a Cruciform Muscle. By Alastair Graham, M.A., B.Sc.(Edin.), Department of Zoology, Birkbeck College, University of London. Communicated by Professor J. H. Ashworth, F.R.S. (With Thirteen Figures.) Issued separately August 20, 1934, .

16. On a New Species of Psygmophyllum from the Upper Carboniferous of Scotland. By Jessie A. R. Wilson, B.Sc., Ph.D., University of Glasgow. Communicated by Professor J. Walton, D.Sc. (With Plate.) Issued separately September 1934,

Obituary Notices: Arthur Henry Hallam Anglin; Frederick Alexander Black; Henry Moubray Cadell; Santiago Ramón y Cajal; George Coull; James Bell Dobbie; James Cossar Ewart; James Haig Ferguson; Sir William Bate Hardy; Sir Alexander Cruikshank Houston; Christopher Nicholson Johnston (Lord Sands); Andrew William Kerr; David Lees; Alexander Veitch Lothian; Sir Donald MacAlister, Bart.; David Clark Thomson Mekie; Sir Thomas Muir; Arthur J. Pressland; Charles Edward Price; Sir Arthur Schuster; Dukinfield Henry Scott; James Young Simpson; Robert Somerville; Duncan M'Laren Young Sommerville; Swale Vincent,

Proceedings of the Statutory General Meeting, October 1933, . . . . $\quad 227$

Proceedings of the Ordinary Meetings, Session 1933-34, . . . . . 230

Proceedings of the Statutory General Meeting, October 1934, . . . 236 
The Keith, Makdougall-Brisbane, Neill, Gunning Victoria Jubilee, James Scott, Bruce, and David Anderson-Berry Prizes, and the Bruce-Preller Lecture Fund,

Awards, .

Accounts of the Society, Session 1933-1934,

* The thanks of the Society are due to the Carnegie Trust for the Universities of Scotland for grants towards the cost of illustrations and tables in this paper and in that by Dr R. A. R. Gresson, published in Proceedings, Vol. LIII, I933, pp. 322-346. 